\title{
Transplantation of betatrophin-expressing adipose-derived mesenchymal stem cells induces $\beta$-cell proliferation in diabetic mice
}

\author{
LIANG-LIANG SUN ${ }^{1 *}$, TIAN-JIN LIU ${ }^{3 *}$, LIMEI LI $^{4 *}$, WEI TANG ${ }^{1}$, JUN-JIE ZOU ${ }^{1}$, XIANG-FANG CHEN ${ }^{1}$, \\ JIAO-YANG ZHENG ${ }^{1}$, BEI-GE JIANG ${ }^{2}$ and YONG-QUAN SHI ${ }^{1}$
}

${ }^{1}$ Department of Endocrinology, Changzheng Hospital, The Second Military Medical University, Shanghai 200003;

${ }^{2}$ Department of Hepatic Surgery, Eastern Hepatobiliary Surgery Hospital, The Second Military Medical University, Shanghai 200438;

${ }^{3}$ Institute of Biochemistry and Cell Biology, Institute of Health Sciences, Shanghai Institutes for Biological Sciences, Chinese Academy of Sciences, Shanghai 200031; ${ }^{4}$ Clinical and Translational Research Center Shanghai East Hospital, Key Laboratory of Arrhythmias of Ministry of Education, Shanghai 200120, P.R. China

Received January 22, 2016; Accepted February 14, 2017

DOI: $10.3892 / \mathrm{ijmm} .2017 .2914$

\begin{abstract}
Recent progress in regenerative medicine has suggested that mesenchymal stem cell (MSC)-based therapy is a novel potential cure for diabetes. Betatrophin is a newly identified hormone that can increase the production and expansion of insulin-secreting $\beta$-cells when administered to mice. In this study, we evaluated the effect of betatrophin overexpression by human adipose-derived MSCs (ADMSCs) by in vitro experiments, as well as following their transplantation into a mice with streptozotocin (STZ)-induced diabetes. The overex-
\end{abstract}

Correspondence to: Dr Yong-Quan Shi, Department of Endocrinology, Changzheng Hospital, Second Military Medical University, 415 Road Fengyang, Shanghai 200003, P.R. China

E-mail: young.stone@163.com

Dr Bei-Ge Jiang, Department of Hepatic Surgery, Eastern Hepatobiliary Surgery Hospital, Second Military Medical University, 225 Road Changhai, Shanghai 200438, P.R. China

E-mail: jiang_beige@aliyun.com

${ }^{*}$ Contributed equally

Abbreviations: ADMSCs, adipose-derived mesenchymal stem cells; bFGF, basic fibroblast growth factor; Bcl-xL, B-cell lymphomaextra large, Bcl-2, B-cell lymphoma 2; ELISA, enzyme-linked immunosorbent assay; EGF, epidermal growth factor; GSIS, glucosestimulated insulin secretion; HGF, hepatocyte growth factor; IGF-1, insulin-like growth factor-1; MSCs, mesenchymal stem cells; MOI, multiplicity of infection; PI, propidium iodide; SD, standard deviation; STZ, streptozotocin; T2D, type 2 diabetes; T1D, type 1 diabetes; $\mathrm{XIAP}, \mathrm{X}$-linked inhibitor of apoptosis protein

Key words: adipose-derived mesenchymal stem cells, betatrophin, islets, streptozotocin-induced diabetes, transplantation pression of betatrophin did not affect the ADMSCs in terms of proliferation, differentiation and morphology. However, the co-culture of human islets with ADMSCs overexpressing betatrophin (ADMSCs-BET) induced islet proliferation, $\beta$-cell specific transcription factor expression, and the islet production of insulin under the stimulation of glucose or $\mathrm{KCl}$ and Arg. In addition, ADMSCs-BET enhanced the anti-inflammatory and anti-apoptotic effects of the co-cultured islets compared with ADMSCs cultured alone. In mice with STZ-induced diabetes, the transplantation of ADMSCs-BET ameliorated the hyperglycemia and weight loss associated with STZ-induced diabetes; ADMSCs-BET also significantly enhanced the ratio of $\beta$-cells per islet compared to the transplantation of ADMSCs alone. Thus, our study demonstrates a novel strategy for inducing $\beta$-cell regeneration. ADMSCs-BET may replace insulin injections by increasing the number of endogenous insulin-producing cells in patients with diabetes. This combined strategy of ADMSC transplantation and gene therapy may prove to be a useful therapy for the treatment of diabetes.

\section{Introduction}

Diabetes mellitus, a complex metabolic disease, has become one of the most serious threats to global public health with an estimated worldwide prevalence of 285 million cases in the adult population (1). In both type 1 diabetes (T1D) and type 2 diabetes (T2D), an inadequate mass of functional pancreatic $\beta$-cells is the major determinant for the onset of hyperglycemia and the development of overt disease $(2,3)$. A variety of pharmacological treatments for diabetes, including insulin therapy, exhibit limited ability to mimic the physiology of insulin secretion and are frequently associated with severe hypoglycemic comas (4). To overcome the limitations of traditional treatment, replenishing the lost insulin-producing cells by transplantation or by the expansion of existing pancreatic $\beta$-cells is the preferred approach for achieving glucose homeostasis (5). 
Recent advances in the identification of stem cells that possess the potential to differentiate into insulin-producing cells and improve pancreatic regeneration provide future treatment options (6). Mesenchymal stem cells (MSCs) have received attention as they can be easily isolated from bone marrow and rapidly expanded ex vivo (7) and do not induce major toxicity following transplantation (8). MSC transplantation can improve the metabolic profiles of diabetic animal models $(9,10)$, and the co-infusion of insulin-secreting adiposederived MSCs with bone marrow-derived hematopoietic stem cells has been shown to control hyperglycemia in patients with T1D (11); however, the mechanisms underlying these beneficial effects remain poorly understood. As the number of MSCs that differentiate into functionally competent $\beta$-cells in vivo is too low to support a physiological change ( $1.7-3 \%$ of infused MSCs) (12), there may be another mechanism underlying their therapeutic effects. MSCs may contribute to tissue regeneration through their immunomodulatory potential $(13,14)$. Furthermore, MSCs secrete anti-inflammatory cytokines and inhibit the expression of pro-inflammatory cytokines by immune cells $(15,16)$. Finally, MSCs produce trophic factors, such as epidermal growth factor (EGF), hepatocyte growth factor (HGF), insulin-like growth factor-1 (IGF-1) and basic fibroblast growth factor (bFGF) $(17,18)$.

Betatrophin, also known as lipasin (19) or angiopoietin-like 8 (20), was recently described as a potent stimulator of mouse $\beta$-cell proliferation (21). Its transient overexpression in the liver induces $\beta$-cell proliferation and improves glucose tolerance in young adult mice (21). However, betatrophin knockout mice do not display an altered glucose homeostasis (22). In patients with T2D, betatrophin levels are associated with measures of insulin resistance; however, studies assessing its level in individuals with T2D have provided conflicting results, with some reporting its increase in patients with T2D (23), while others have shown that it is decreased in these same patients (24). As the mechanisms through which betatrophin improves diabetes mellitus remains unknown (25), in this study, we aimed to evaluate the in vitro and in vivo effects of lentivirus-induced betatrophin overexpression in adipose-derived MSCs (ADMSCs). The biological characteristics and differentiation potential of the betatrophinoverexpressing ADMSCs (ADMSCs-BET) were assessed in vitro. Furthermore, their effects on pancreatic $\beta$-cells were examined via co-culture with pancreatic islets and transplantation into mice with streptozotocin (STZ)-induced diabetes. Our findings have the potential to form the basis for further clinical analysis of combining MSC transplantation with gene therapy as a novel therapy for the treatment of diabetes.

\section{Materials and methods}

Adenoviruses and gene transfer. Human ADMSCs were obtained from the Typical Culture Preservation Commission Cell Bank, Chinese Academy of Sciences (Shanghai, China). The ADMSCs were cultured in MesenPro RS medium (Life Technologies, Carlsbad, CA, USA). A cDNA fragment containing the full-length coding regions of betatrophin was obtained from the cDNA library of human vascular endothelial cells (the Typical Culture Preservation Commission Cell Bank) by a RT-PCR method, using a reverse transcription PCR
Table I. PCR primers used for RT-qPCR.

\begin{tabular}{|c|c|}
\hline Gene & Primer sequences $\left(5^{\prime} \rightarrow 3^{\prime}\right)$ \\
\hline \multirow[t]{2}{*}{ Betatrophin } & ATGGGATCCATGCCAGTGCCTGCTCTGTGCCTG \\
\hline & ATGGTCGACTCAGGCTGGGAGCGCCGCTGTGTG \\
\hline \multirow[t]{2}{*}{ Insulin } & CCGTCGTGAAGTGGAG \\
\hline & CAGTTGGTAGAGGGAGCAG \\
\hline \multirow[t]{2}{*}{ Glucagon } & AGCTGCCTTGTACCAGCATT \\
\hline & TGCTCTCTCTTCACCTGCTCT \\
\hline \multirow[t]{2}{*}{ Glut2 } & TTACTCTCCATTTCAGTCCTTTGT \\
\hline & TAGAGCAGCTCTTTATTCCAGATTT \\
\hline \multirow[t]{2}{*}{ Foxa2 } & CCCCTGAGTTGGCGGTGGT \\
\hline & TTGCTCACGGAAGAGTAGCC \\
\hline \multirow[t]{2}{*}{$N k x 2.2$} & ACCACAGTCCATGCCATCAC \\
\hline & TGCCCGCCTGGAAGGTGGCG \\
\hline \multirow[t]{2}{*}{$\operatorname{Pax}-4$} & CGACAAGATTTGCCATGGAT \\
\hline & CAACCTTTGGAAAAACCAACA \\
\hline \multirow[t]{2}{*}{ Pax-6 } & CAGCTTGGTGGTGTCTTTGTC \\
\hline & CCCTCGGATAATAATCTGTCTCG \\
\hline \multirow[t]{2}{*}{$\mathrm{NeoD}$} & ATCAGCCCACTCTCGCTGTA \\
\hline & GCCCCAGGGTTATGAGACTAT \\
\hline \multirow[t]{2}{*}{ Ngn3 } & CCGGACATCTCCCCATACGAAG \\
\hline & ACACCAGTGCTCCGGCTCT \\
\hline \multirow[t]{2}{*}{$\operatorname{MafB}$} & AGCAGGGTTTGAAATTGATCC \\
\hline & GCATGGTGCTTGCAGTTTTA \\
\hline \multirow[t]{2}{*}{ MafA } & ATCATCACTCTGCCCACCAT \\
\hline & AGTCGGATGACCTCCTCCTT \\
\hline \multirow[t]{2}{*}{$\beta$-actin } & GAGACCTTCAACACCCCAGC \\
\hline & ATGTCACGCACGATTTCCC \\
\hline
\end{tabular}

Glut2, glucose transporter 2; Foxa2, forkhead box A2; Nkx2.2, NK2 homeobox 2; Pax, paired box gene; NeoD, 2-deoxystreptamine N-acetyl-Dglucosaminyltransferase; Ngn3, neurogenin 3.

kit (Toyobo Co., Ltd, Osaka, Japan). The recombinant adenovirus, expressing either $\beta$-galactosidase (LacZ) or betatrophin, was generated using cosmid cassettes and the adenovirus DNA-terminal protein complex method (COS/TPC method), with an Adenovirus Expression vector kit (Takara, Osaka, Japan). For lentivirus-mediated gene transfer, the MSCs were exposed to lentiviral vectors at a multiplicity of infection (MOI) of approximately 10-20 for $12 \mathrm{~h}$.

Reverse transcription-quantitative polymerase chain reaction $(R T-q P C R)$. Total RNA was extracted from cells and the mouse livers using TRIzol reagent (Life Technologies). Reverse transcription was performed using MMLV reverse transcriptase (Thermo Fisher Scientific, Waltham, MA, USA), and the PCR reaction was performed using the SYBR-Green PCR Master Mix (Life Technologies). The PCR primers used in this study are listed in Table I. Each reaction mixture was incubated at $50^{\circ} \mathrm{C}$ for $2 \mathrm{~min}$ and $95^{\circ} \mathrm{C}$ for $5 \mathrm{~min}$ followed by 40 cycles of $15 \mathrm{sec}$ at $95^{\circ} \mathrm{C}$ and $35 \mathrm{sec}$ at $60^{\circ} \mathrm{C}$ using an 
ABI 7500 Sequence detection system (Applied Biosystems, Foster City, CA, USA). The corresponding relative mRNA expression was normalized to $\beta$-actin and was calculated using the $2^{-\Delta \Delta C q}$ method.

Western blot analysis. Cell lysates $(50 \mu \mathrm{g})$ were separated by $12 \%$ sodium dodecyl sulfate-polyacrylamide gel electrophoresis (SDS-PAGE) and blotted onto polyvinylidene fluoride (PVDF) membranes (Amersham Biosciences, Uppsala, Sweden). After blocking with 5\% skim milk, the membranes were then blotted with the indicated primary antibodies: mouse anti-human betatrophin antibody (1:200; AG-25B-0033-C100; Adipogen, San Diego, CA, USA), rabbit anti-human insulin (1:200; Cat. no. 3014; Cell Signaling Technology, Danvers, MA, USA), active caspase-3 (1:200; Cat. no. 9661S; Cell Signaling Technology), mouse anti-human glyceraldehyde 3-phosphate dehydrogenase (GAPDH) (1:5,000; ab110305; Abcam, Cambridge, UK), or mouse anti-human $\beta$-actin (1:10,000; A5441-100UL; Sigma-Aldrich, St. Louis, MO, USA). After washing, the membranes were incubated with the horseradish peroxidase (HRP)-conjugated secondary antibody at room temperature for $1 \mathrm{~h}$ : either goat anti-rabbit $\operatorname{IgG}(1: 8,000$; AS10 668; Epitomics Inc., Burlingame, CA, USA) or rabbit anti-mouse IgG (1:10,000; A9044-2ML; Sigma-Aldrich). The protein intensity was determined by ECL chemiluminescence reagent (PerkinElmer Life Sciences, Inc., Waltham, MA, USA), and their intensities were quantitatively measured by densitometry (LabWorks, UVP Inc., Upland, CA, USA).

Cell cycle analysis. The ADMSCs were seeded at $0.2 \times 10^{6}$ cells $/ 25 \mathrm{~cm}^{2}$ flask. At $80-90 \%$ confluence, the cells were harvested for cell cycle analysis. Briefly, the cells were washed and fixed in $70 \%$ ethanol overnight at $-20^{\circ} \mathrm{C}$. The fixed cells were then washed and incubated in $100 \mu \mathrm{g} / \mathrm{ml}$ propidium iodide (PI) and $20 \mathrm{ng} / \mathrm{ml}$ RNAase (both from Sigma-Aldrich) in phosphate-buffered saline (PBS) for $30 \mathrm{~min}$. Cell cycles were assessed by flow cytometry, and analysis was performed using FCS Express V3 software (BD Biosciences, San Jose, CA, USA).

Flow cytometry. The ADMSCs were analyzed for the surface expression of a battery of markers at passage 4 (P4). Anti-mouse antibodies purchased from BD Biosciences included CD45 (FITC-conjugated, Cat. no. 553099), CD14 (FITC-conjugated, Cat. no. 553739), CD90 (APC-conjugated, Cat. no. 553007) and CD73 (PE-conjugated, Cat. no. 550741). Antibodies against CD105 (PE-conjugated, Cat. no. 25-1057-41) were purchased from eBioscience (San Diego, CA, USA). A total of $1 \times 10^{6}$ cells were incubated with fluorescent-conjugated antibodies for $30 \mathrm{~min}$ at room temperature followed by analysis using a Becton-Dickinson FACSCalibur (BD Biosciences, Franklin Lakes, NJ, USA) and CellQuest Pro software.

To assess apoptosis, the ADMSC/islet co-cultures were dissociated with Liberase (Roche Life Science, Basel, Switzerland) and the stained with FITC Annexin V and PI (BD Biosciences) followed by flow cytometric analysis.

ADMSC differentiation assays. To examine whether betatrophin overexpression alters the differentiation capacity of ADMSCs (ADMSCs-BET), the cells were induced to undergo adipogenic, osteogenic and chondrogenic differentiation. Adipogenic and osteogenic differentiation were induced as previously described (26). The acquisition of the adipogenic phenotype was determined by staining the monolayers with a 0.5\% Oil Red O solution (O1391-250ML; Sigma-Aldrich). ADMSC colonies that underwent adipogenic differentiation contained cells with numerous lipid vesicles of various sizes. Osteogenic mineralization was assessed by staining with 40 mM Alizarin Red, pH 4.1 (Sigma-Aldrich).

For chondrogenic differentiation, the pellet culture system described by Sekiya et al (27) was used. ADMSC pellets were cultured in chondrogenic differentiation medium, which consisted of DMEM supplemented with $500 \mathrm{ng} / \mathrm{ml}$ bone morphogenic protein-6 (BMP-6; R\&D Systems, Minneapolis, MN, USA), $10 \mathrm{ng} / \mathrm{ml}$ tumor growth factor- $\beta 3$ (TGF- $\beta 3$ ), $10^{-7} \mathrm{M}$ dexamethasone, $50 \mu \mathrm{g} / \mathrm{ml}$ ascorbate 2-phosphate, $40 \mu \mathrm{g} /$ $\mathrm{ml}$ proline, $100 \mu \mathrm{g} / \mathrm{ml}$ pyruvate and $50 \mathrm{mg} / \mathrm{ml} \mathrm{ITS} \mathrm{+} \mathrm{premix}$ (Becton-Dickinson: $6.25 \mu \mathrm{g} / \mathrm{ml}$ insulin, $6.25 \mu \mathrm{g} / \mathrm{ml}$ transferrin, $6.25 \mathrm{ng} / \mathrm{ml}$ selenous acid, $1.25 \mathrm{mg} / \mathrm{ml}$ bovine serum albumin, $5.35 \mathrm{mg} / \mathrm{ml}$ linoleic acid). The medium was replaced every 2-3 days for 21 days. Pellets were then fixed in formalin, embedded in paraffin and sectioned, and the sections were stained with Toluidine blue (198161; Sigma-Aldrich).

Collection of human islets. Human islets were collected from patients who underwent pancreaticoduodenal surgery at the Eastern Hepatobiliary Hospital, Shanghai, China between September 2012 and January 2013. Six male patients (age range, 52-63 years) were recruited. Patients with known distal metastasis and portal vein tumor thrombus were excluded; pancreatic involvement was not observed during surgery. As cholangiocarcinoma invades the distal common bile duct, duodenopancreatectomy (Whipple's surgery) was also required. This study was approved by the Institutional Review Board of the Second Military Medical University, and all participants provided informed consent.

Co-culture of ADMSCs with islets. The ADMSCs or ADMSCs-BET were seeded at the density of $1.0 \times 10^{6}$ cells to a $100 \mathrm{~mm}$ low adherence culture dish (Corning, Corning, NY, USA) with 500 human islets in $10 \mathrm{ml}$ culture medium, as previously described (28). Islets cultured alone were used as controls. The culture medium consisted of DMEM low glucose (5.6 mM glucose) with $1 \%$ fetal bovine serum (FBS), $20 \mathrm{ng} / \mathrm{ml}$ EGF, $20 \mathrm{ng} / \mathrm{ml}$ bFGF, $10 \mathrm{mM}$ HEPES, 100 units penicillin/1,000 units streptomycin and $71.5 \mu \mathrm{M}$ $\beta$-mercaptoethanol for $48 \mathrm{~h}$. DMEM low glucose, FBS, EGF, $\mathrm{bFGF}$ and penicillin/streptomycin were purchased from Life Technologies. HEPES and $\beta$-mercaptoethanol were obtained from Sigma-Aldrich.

Immunohistochemical staining. For immunohistochemical staining, pancreatic tissue sections were blocked by incubation in $2.5 \%$ bovine serum albumin for $20 \mathrm{~min}$ at room temperature. The sections were then incubated with mouse anti-vimentin (1:400; ab92547), rabbit anti-insulin (1:500; ab63820) or antiKi67 (1:500; ab15580) (all from Abcam) antibodies overnight at $4{ }^{\circ} \mathrm{C}$, followed by fluorescein isothiocyanate-conjugated antimouse (SA1062) or anti-rabbit (SA1064) secondary antibodies (1:200; Boster, Wuhan, China) for $2 \mathrm{~h}$ at room temperature. The 
nuclei were stained with 4,6-diamidino-2-phenylindole (DAPI) for a further 40-60 min. The tissue sections were assessed using a fluorescence microscope (Leitz, Wetzlar, Germany). Image acquisition was performed with the SPOT RT Imaging system (Diagnostic Instruments, Sterling Heights, MI, USA). In addition, the ratio of $\beta$-cells per islet (i.e., the number of $\beta$-cells over the total number of islet cells) was measured using Image-Pro 6.0 Image-Pro Plus version 6.0 (MediaCybernetics, Rockville, MD, USA).

Insulin secretion assays. Glucose-independent insulin secretion was triggered by membrane depolarization that was induced by a combination of $30 \mathrm{mM} \mathrm{KCl}$ (A610440-0500; Sangon Biotech Co., Ltd., Shanghai, China) and $30 \mathrm{mM} \mathrm{Arg}$ (A600205-0100; Sangon Biotech Co., Ltd.) at 20 and $50 \mathrm{~min}$ after the experiment began, as previously described (29). Glucose-stimulated insulin secretion (GSIS) was used to assess human islet function in the presence of 60 and $300 \mathrm{mg} / \mathrm{l}$ glucose. A total of $20 \mu \mathrm{l}$ was removed at $0,10,20,30$ up to $90 \mathrm{~min}$, and secreted insulin level was measured by enzymelinked immunosorbent assay (ELISA; Crystal Chem, Downers Grove, IL, USA) following the manufacturer's instructions.

Measurement of the adenosine triphosphate (ATP)/adenosine diphosphate $(A D P)$ ratio. The ADP/ATP ratio was determined using the ADP/ATP Ratio Assay kit (Cat. no. MAK135; SigmaAldrich) according to the manufacturer's instructions. Briefly, the cells $(4,000 /$ well) were seeded in a 96-well, flat-bottom, white plate with clear bottoms. The ATP level was assayed by a luminometric method. After removing the culture medium, $100 \mu \mathrm{l}$ of nucleotide releasing buffer was added and incubated for $5 \mathrm{~min}$. The samples were mixed with $100 \mu \mathrm{l}$ of a commercially available lyophilized ATP monitoring reagent containing firefly luciferase and luciferin at first reconstituted in an imidazole buffer (100 mM, pH 7.75). The emitted light was measured using a BioTek luminometer. The ADP/ATP ratio of the 3 different groups was detected. All assays were performed in triplicate.

Quantification of secreted proteins. The levels of interleukin (IL)-4, IL-10, IL-13, IL1- $\beta$, tumor necrosis factor- $\alpha$ (TNF- $\alpha$ ), NADP-cytochrome P450 reductase (NCP1), $\mathrm{X}$-linked inhibitor of apoptosis protein (XIAP), B-cell lymphoma-extra large (Bcl-xL) and B-cell lymphoma-2 (Bcl-2) secreted by the ADMSCs in co-culture with pancreatic islets were measured using the RayBio human growth factor antibody array (RayBiotech, Norcross, GA, USA). ADMSCs were maintained in MesenPro medium (Invitrogen, Carlsbad, CA, USA) for 2 days, and the conditioned medium was then collected for growth factor array analysis according to the manufacturer's instructions. MesenPro medium served as the control.

Induction of diabetes and ADMSC transplantation. This study was approved by the Institutional Animal Care and Use Committee of the Second Military Medical University. T1D was induced in 10-week-old BALB/c mice $(n=40$, weighting 25-27 g, obtained from the Shanghai SLAC Laboratory Animal Co., Ltd, Shanghai, China) by an intraperitoneal injection of STZ Sigma-Aldrich) at a dose of $60 \mathrm{mg} / \mathrm{kg}$ body weight in $25 \mathrm{mM}$ sodium citrate ( $\mathrm{pH} 4.5$ ), as previously described (30). The onset of diabetes was defined as elevated blood glucose values of $>200 \mathrm{mg} / \mathrm{dl}$ found at two consecutive tests at 3-day intervals. Blood glucose was measured after an 8-h fast.

The diabetic mice were further divided into the following 3 groups ( $n=8$ per group) as follows: the diabetic (control) group, the diabetic mice with ADMSC transplantation group, and the diabetic mice with ADMSC-BET transplantation group. For ADMSC transplantation, $1 \times 10^{6}$ cells in $0.2 \mathrm{ml}$ of PBS were injected into the diabetic mice via the tail vein 7 weeks after the STZ injection. In the control group, $0.2 \mathrm{ml}$ of PBS was injected into the diabetic mice via the tail vein at the same time points as those for ADMSC transplantation.

Quantification of betatrophin and C-peptide. The animals were sacrificed at 28 days, and the levels of betatrophin in homogenized liver samples and plasma were then quantified using an EIA kit (Phoenix Pharmaceuticals, Belmont, CA, USA) following the manufacturer's instructions. The plasma level of C-peptide was measured by an EIA kit (BioVision, San Francisco, CA, USA) following the manufacturer's instructions.

Statistical analysis. Values are expressed as the means \pm standard deviation(SD). Differences between groups were examined by one-way ANOVA, followed by Bonferroni post-hoc tests. Statistical assessments were evaluated at a two-sided significance level of 0.05, and performed using IBM SPSS software, version 22 (IBM Corp., Armonk, NY, USA).

\section{Results}

Generation and characterization of ADMSCS-BET. We overexpressed betatrophin in ADMSCs using a lentivirus. A significantly higher mRNA and protein expression level was detected in the ADMSCs-BET compared with the control group consisting of ADMSCs transfected with the vehicle [the recombinant adenovirus, expressing $\beta$-galactosidase (LacZ)] (Fig. 1A and B, respectively). As compared to mouse hepatic tissue, in which betatrophin is primarily expressed, there was a significantly higher betatrophin mRNA expression in the ADMSCs-BET $(1.0 \pm 0.024$ vs. $8.08 \pm 0.23, \mathrm{P}<0.001)$. These data demonstrate the successful lentiviral-mediated overexpression of betatrophin in ADMSCs.

For clinical application, ADMSCs-BET should have the biological properties of ADMSCs. As shown in Fig. 1C, the ADMSCs-BET and ADMSCs exhibited a similar fibroblast-like morphology. Similar cell cycle progression was also observed with 52.2 and $42 \%$ of the ADMSCs and ADMSCs-BET in the $\mathrm{S}+\mathrm{G} 2 / \mathrm{M}$ phases, respectively (Fig. 1D). As the surface marker profile and differentiation potential are thought to be minimal criteria for MSCs (31), we tested an array of surface markers by flow cytometry. As shown in Fig. 2A, both the ADMSCs and ADMSC-BET were positive for CD73, CD90 and CD105, and negative for CD14 and CD45. Furthermore, both the ADMSCs and ADMSCs-BET had the capacity to differentiate into adipogenic, osteogenic and chondrogenic lineages in vitro (Fig. 2B), as has also been demonstrated by previous studies $(32,33)$. Thus, the overexpression of betatrophin did not alter the biological characteristics of the ADMSCs.

Islet-MSC-BET co-culture enhances islet viability and $\beta$-cell insulin secretion. To identify whether betatrophin overexpres- 

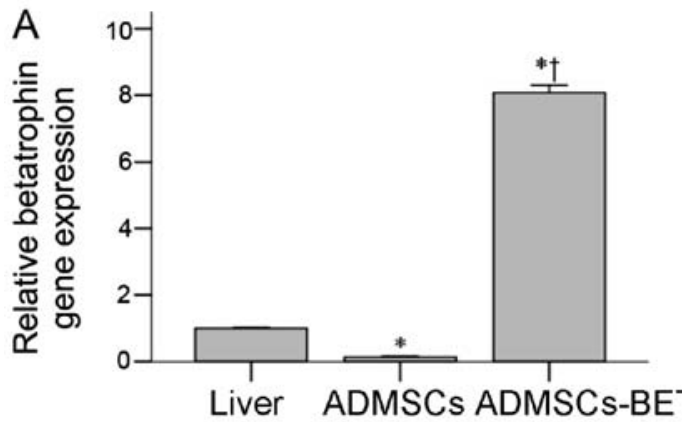

C

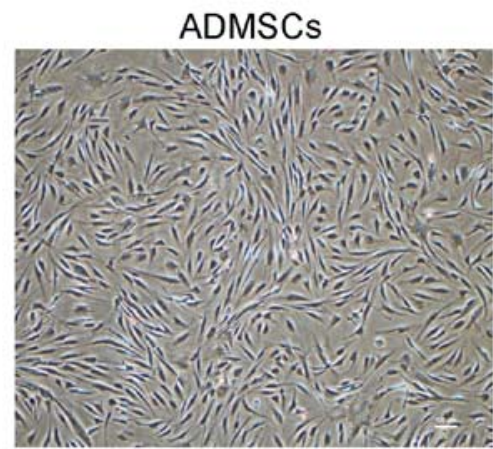

ADMSCs-BET

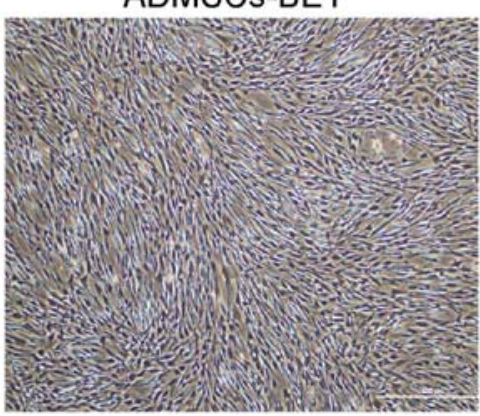

$\mathrm{B}$

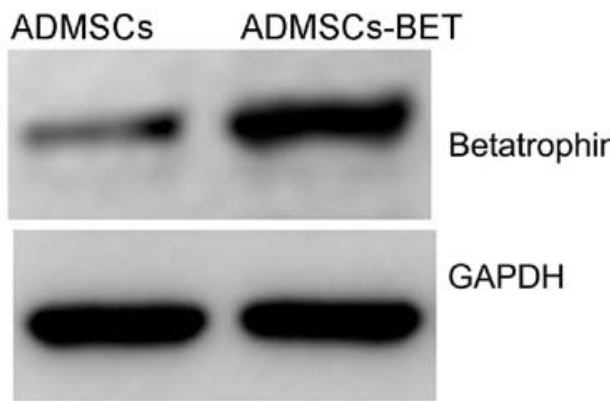

D

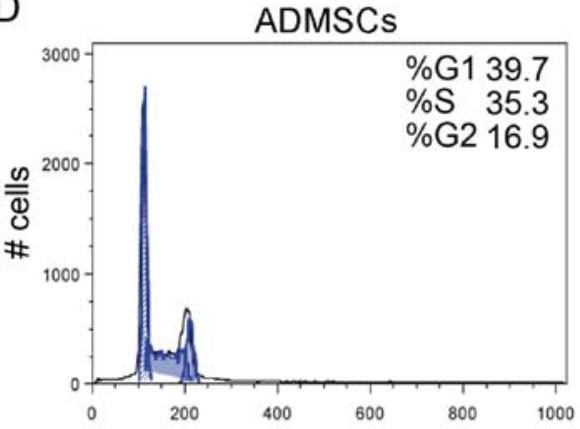

ADMSCs-BET

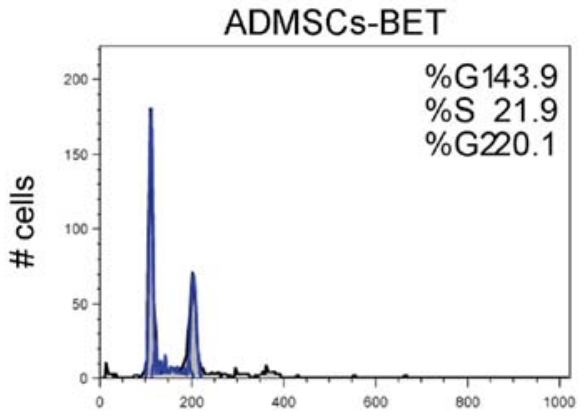

Figure 1. Biological characteristics of adipose-derived mesenchymal stem cells (ADMSCs) overexpressing betatrophin. (A) RT-qPCR of betatrophin mRNA expression following transduction of ADMSCs with a control lentivirus (MSC) and betatrophin-expressing lentivirus (MSC-BET). Data represent the mean \pm standard deviation; $\mathrm{n}=3$ for each bar. (B) Western blot analysis for betatrophin expression following transduction of ADMSCs with a control lentivirus (ADMSCs) and betatrophin-expressing lentivirus (ADMSCs-BET). (C) Phase contrast images of adherent fibroblast-like AdMSCs and AdMSCs-BET. (D) Histogram of ADMSCs stained with PI. The G0/G1 and G2/M peaks are separated by the S phase distribution.

sion provides additional benefits beyond ADMSCs on the viability and function of islets, ADMSCs-BET or ADMSCs were co-cultured with human islets as previously described (34). Co-culture of the islets with ADMSCs-BET induced a marked increase in the size of the islets, as well as the formation of new islet-like aggregates of cells; no such changes were observed with the ADMSCs alone (Fig. 3, top row). Furthermore, the expression of Ki67 antigen, a nuclear marker of cell proliferation, was substantially increased in the islets co-cultured with ADMSCs-BET compared with the islets co-cultured with ADMSCs or cultured alone (Fig. 3, bottom row). The proportion of Ki67-positive cells in the ADMSCs-BET + islet group was significantly greater than that of the other 2 groups $(\mathrm{p}<0.0167)$. The analysis of insulin mRNA levels revealed that the islets co-cultured with ADMSCs expressed markedly higher levels than the islets cultured alone $(4.15 \pm 0.54$ vs. $1.10 \pm 0.56$, respectively; $\mathrm{P}<0.001$ ) (Fig. 4A). The insulin mRNA levels of the islets co-cultured with ADMSCs-BET were significantly higher than those cultured with ADMSCs or alone (8.52 \pm 0.19 vs. $4.15 \pm 0.54$ and $1.10 \pm 0.56$, respectively; both $\mathrm{P}<0.001)$. By contrast, all 3 groups expressed similar glucagon mRNA levels ( $\mathrm{P}>0.05)$.

The mRNA expression of a panel of regulatory factors related to insulin transcription was then analyzed. Co-culture with both ADMSCs and ADMSCs-BET significantly upregulated the Foxa2, Nkx2.2, Pax4, Pax6, NeuroD and MafB mRNA levels (all $\mathrm{P} \leq 0.002$ ) (Fig. 4B). In addition, the Foxa2, Pax4 and neuroD mRNA levels were further increased following co-culture with ADMSCs-BET compared to co-culture with ADMSCs (all P $\leq 0.013$ ). Of note, the Pax6 mRNA levels were decreased with ADMSCs-BET co-culture as compared to co-culture with ADMSCs $(\mathrm{P}=0.005)$; however, the mRNA levels of Glut2 and MafA were only induced following co-culture with ADMSCs-BET ( $\mathrm{P} \leq 0.001)$.

As shown in Fig. $4 \mathrm{C}, \mathrm{KCl}$ and Arg induced strong and equivalent insulin secretion by islets co-cultured with ADMSCs and ADMSCs-BET; however, the insulin levels in the ADMSCs-BET + islet group were significantly higher than 
A
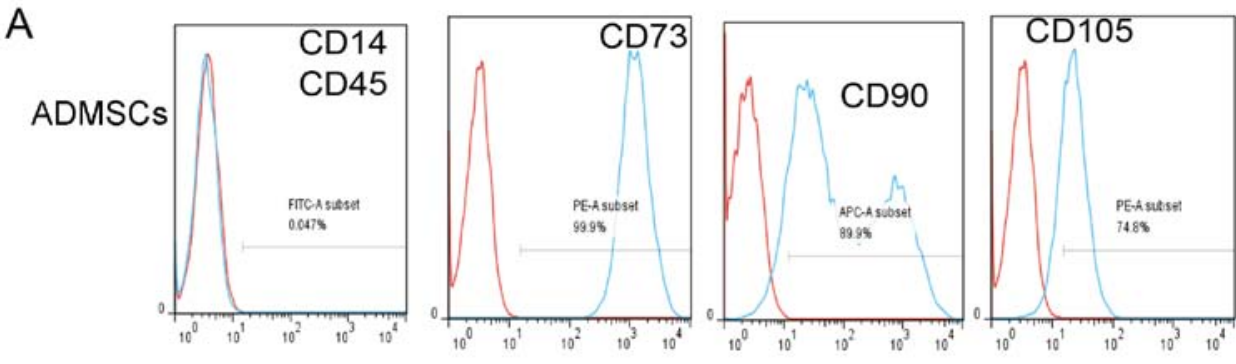

fito.

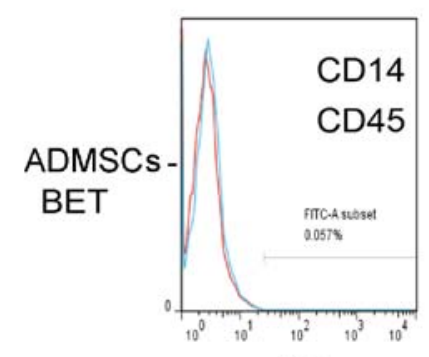

B
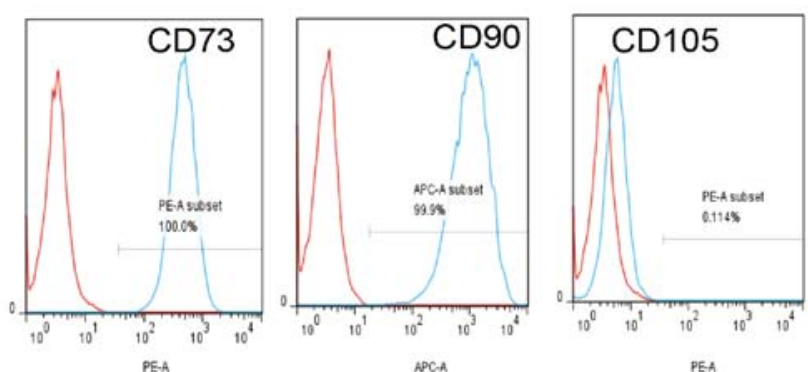

APCA

PEA

Adipogenic differentiation

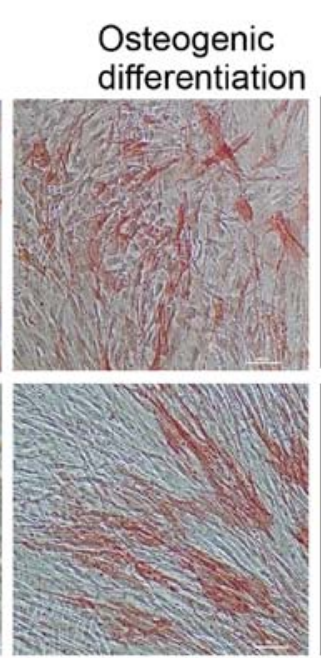

Chondrogenic differentiation
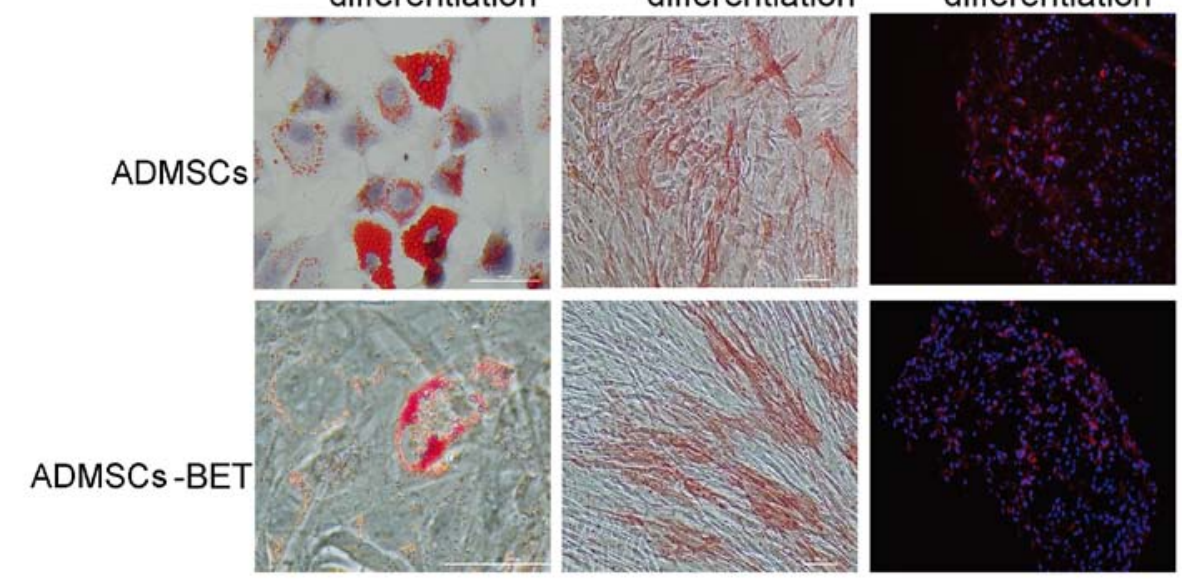

Figure 2. Surface phenotype and differentiation ability of adipose-derived mesenchymal stem cells (ADMSCs) overexpressing betatrophin. (A) ADMSCs and ADMSCs-BET were incubated with specific surface marker antibodies or isotype control antibodies and subjected to flow cytometry analysis. (B) Representative images of ADMSCs and ADMSCs-BET differentiation. Images are shown at x100 magnification.

those in the ADMSCs + islet group and islet alone group at 20 and $50 \mathrm{~min}(\mathrm{P}<0.001)$. The analysis of GSIS in the presence of 60 and $300 \mathrm{mg} / \mathrm{l}$ glucose revealed that the islets cultured with both ADMSCs and ADMSCs-BET secreted significantly more insulin than the islets cultured alone $(\mathrm{P}<0.001)$ (Fig. 4D). Furthermore, ADMSCs-BET induced significantly greater glucose-stimulated insulin secretion compared to the ADMSCs $(\mathrm{P}<0.001)$.

The analysis of the ADP/ATP ratio revealed that co-culture with ADMSCs and ADMSCs-BET produced lower ADP/ATP ratios than the islets cultured alone (both $\mathrm{P}<0.001$ ) (Fig. 4E). The ADMSCs-BET were significantly more effective in reducing the ADP/ATP ratio $(\mathrm{P}=0.003)$. Taken together, these results suggest that the islets cultured with ADMSCs-BET displayed an enhanced viability and insulin secretory function and reduced ADP/ATP ratios beyond those observed with ADMSC co-culture.

Expression of betatrophin enhances the anti-inflammatory and anti-apoptotic potential of ADMSCs. Pro-inflammatory cytokines can cause impaired function, and ultimately the cell death of islets by apoptosis or necrosis in T1D, and inflammation may participate in the pathogenesis of T2D (35). In addition, inflammation-induced apoptosis plays a significant role in the loss of islet function immediately after islet transplantation $(36,37)$. Moreover, anti-inflammatory cytokines are protective against pancreatic $\beta$-cell death $(38,39)$. Thus, we measured the levels of several inflammatory- and apoptosisrelated proteins in the supernatant of the co-culture system. As shown in Fig. 5A, the L-4, IL-10 and IL-13 protein levels were significantly increased when the islets were co-cultured with either ADMSCs or ADMSCs-BET; the IL-4 levels in the ADMSCs-BET group were significantly higher compared with those in the ADMSCs group (all $\mathrm{P}<0.05$ ). Whereas no differences in IL-1B levels were observed among the 3 groups, the TNF- $\alpha$ and NCP1 levels were significantly decreased in the islets co-cultured with ADMSCs-BET as compared to the control group (both $\mathrm{P}<0.05$ ). In addition, the XIAP, Bcl-xL and Bcl-2 levels were significantly increased in the islets co-cultured with ADMSCs or ADMSCs-BET (all P<0.05); 

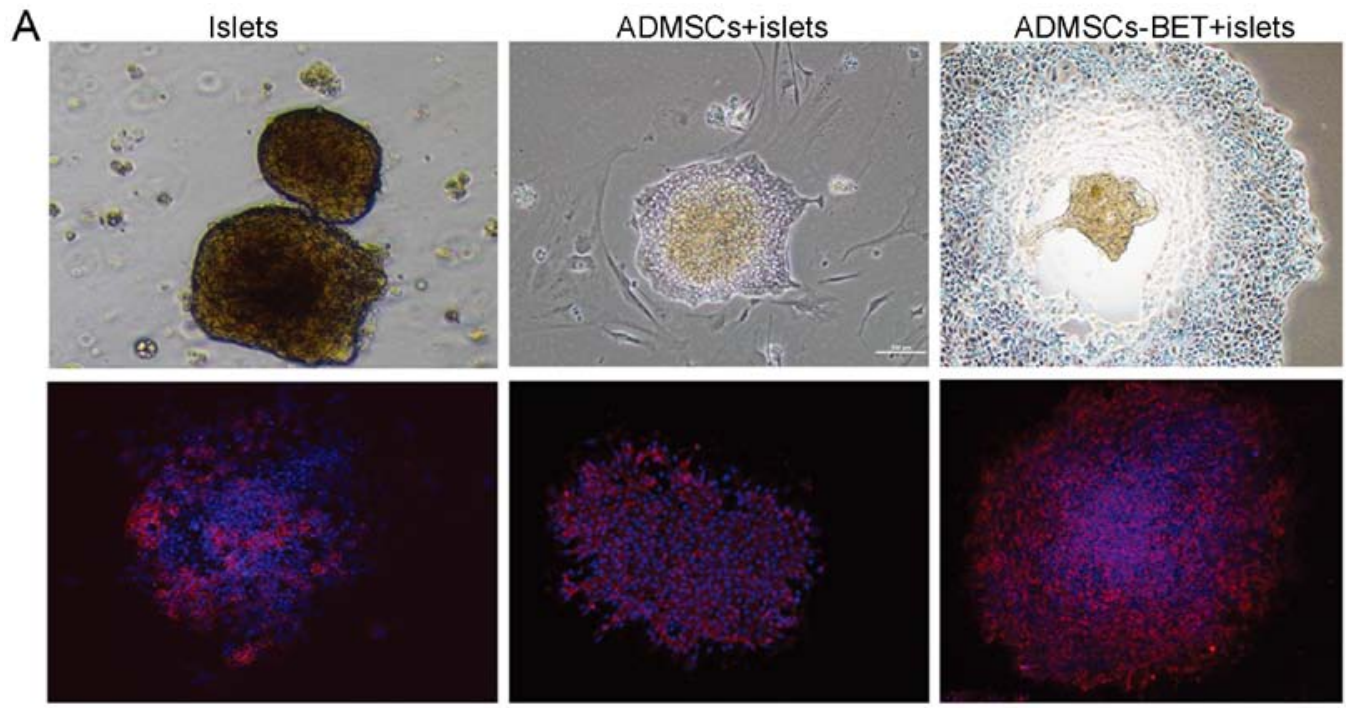

B

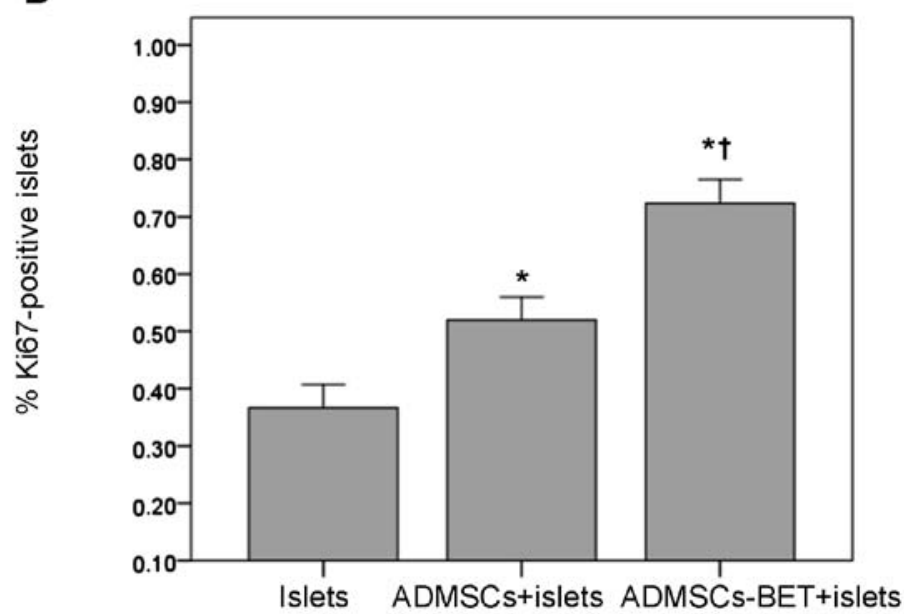

Figure 3. Betatrophin-expressing adipose-derived mesenchymal stem cells (ADMSCs) promote the proliferation of human islets in a co-culture system. (A) Staining for the proliferation marker, Ki67 (red), and nuclei (DAPI, blue) in human islets cultured alone (islet) or with ADMSCs (ADMSCs + islets) or ADMSCs-BET (ADMSCs-BET + islets). (B) Proportion of Ki67-positive cells among islet, ADMSCs + islets, and ADMSCs-BET + islet groups. Data are represented as the means $\pm \mathrm{SD}\left(\mathrm{n}=3\right.$ per condition). ${ }^{*} \mathrm{P}<0.0167$, significant difference compared with "Islets only, and ${ }^{\dagger} \mathrm{ADMSCs}+$ islets.

however, the XIAP and Bcl-xL levels were significantly higher in the ADMSCs-BET group as compared to the ADMSCs group (both $\mathrm{P}<0.05$ ). Furthermore, western blot analysis revealed that the level of active caspase- 3 was reduced in the islets co-cultured with ADMSCs-BET (Fig. 5B), and a decreased amount of apoptotic cells (green fluorescence) was detected in the islets co-cultured with ADMSCs-BET, as shown by Annexin V FITC and PI staining (Fig. 5C). Taken together, ADMSCs have anti-apoptotic and anti-inflammatory effects on islets, and the transduction of betatrophin in ADMSCs appears to provide additional benefits.

Infusion of ADMSCs-BET attenuates hyperglycemia in mice with STZ-induced diabetes. To assess the function of ADMSCs in vivo, a single dose of $1 \times 10^{6}$ ADMSCs or ADMSCs-BET was injected into mice with STZ-induced diabetes via the tail vein. As shown in Fig. 6A, the transplantation of both ADMSCs and ADMSCs-BET significantly reduced the fasting blood glucose levels compared with the control group at days 14, 21 and 28 (all $\mathrm{P}<0.05$ ); however, the reduction in blood glucose levels in mice receiving ADMSCs-BET was significantly greater compared with the mice receiving ADMSCs (all $\mathrm{P}<0.05)$. Consistent with these results, ADMSCs-BET transplantation led to a significant restoration of the ratio of $\beta$-cells/islets (Fig. 6C).

The analysis of the mean body weight revealed that whereas the control group experienced a decrease in body weight over the course of the study, the ADMSCs and ADMSCs-BET groups had significantly increased body weights on days 7-28 (all $\mathrm{P}<0.05$ ) (Fig. 6B). Furthermore, mice in the ADMSCs-BET group had significantly higher body weights compared with those in the ADMSCs group on days 21 and 28 (both $\mathrm{P}<0.05$ ).

As shown in Fig. 7, immunohistochemical analysis of pancreatic tissue revealed an increase in the number of Ki67-positive and insulin-positive cells in the ADMSCs and ADMSCs-BET groups, suggesting that their transplantation 

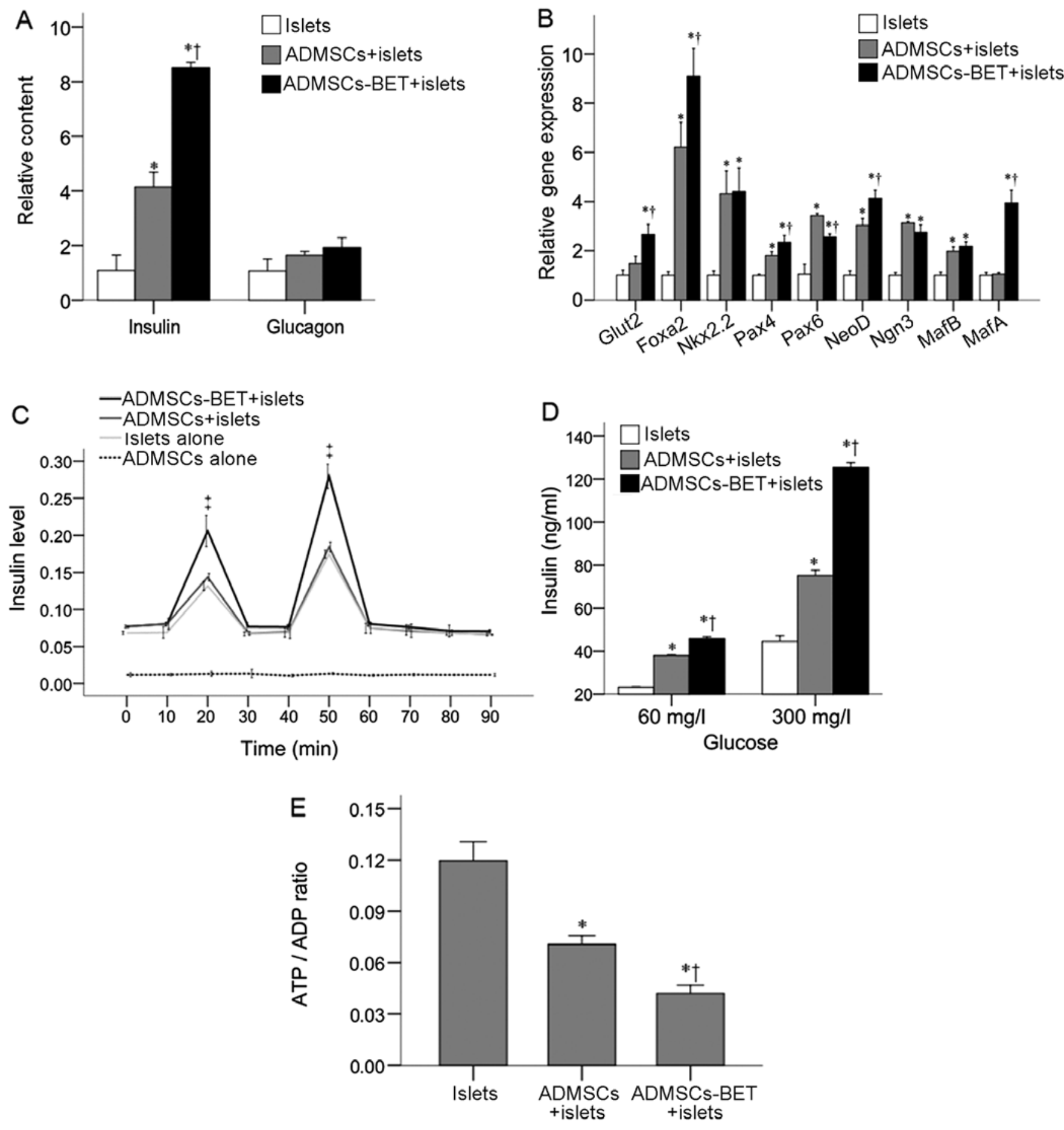

Figure 4. Betatrophin-expressing adipose-derived mesenchymal stem cells (ADMSCs) promote the function of human islets in a co-culture system. (A) Insulin and glucagon mRNA levels in islets cultured alone (islets) or with ADMSCs (ADMSCs + islets) or ADMSCs-BET (ADMSCs-BET + islet). (B) mRNA levels of transcription factors in islets cultured alone (islet) or with ADMSCs (ADMSCs + islet) or ADMSCs-BET (ADMSCs-BET + islets). (C) Insulin levels from the four indicated groups are shown upon stimulation with $\mathrm{Arg}$ and $\mathrm{KCl}$ at 20 and $50 \mathrm{~min}$. (D) Glucose-induced insulin secretion in islets cultured alone (islets) or with ADMSCs (ADMSCs + islets) or ADMSC-BET (ADMSCs-BET + islets) after stimulation with 60 and $300 \mathrm{mg} / \mathrm{dl}$ of glucose. (E) The ADP/ATP ratio of the 3 different groups was detected.

increased $\beta$-cell proliferation, resulting in reduced blood glucose levels in mice with STZ-induced diabetes.

To confirm that mice transplanted with ADMSCs-BET actually had increased betatrophin levels, we evaluated betatrophin levels in the liver and plasma, which were both significantly higher in the ADMSCs-BET group compared to the other 2 groups (all $\mathrm{P}<0.001$ ) (Fig. 8A and B). No significant difference was observed between the control and ADMSCs groups.
As shown in Fig. 8C, the plasma C-peptide levels of the ADMSCs-BET group were significantly higher than those in the control and ADMSCs groups on day 28 (156.85 \pm 19.92 vs. $116.22 \pm 8.01$ and $132.45 \pm 18.01$, respectively; $\mathrm{P}<0.001$ and $\mathrm{P}=0.007$, respectively). Furthermore, although the plasma insulin levels of the ADMSCs group were significantly higher than those in the control group $(9.22 \pm 1.89$ vs. $6.73 \pm 1.24$, respectively; $\mathrm{P}=0.003$ ) (Fig. $8 \mathrm{D}$ ), they were highest in the 


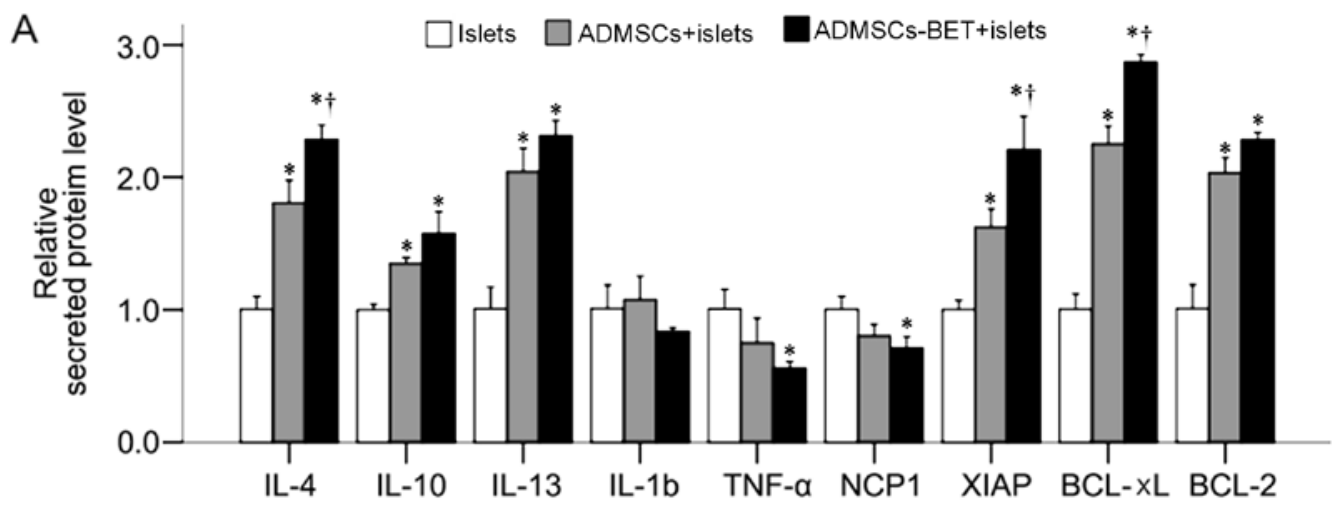

B
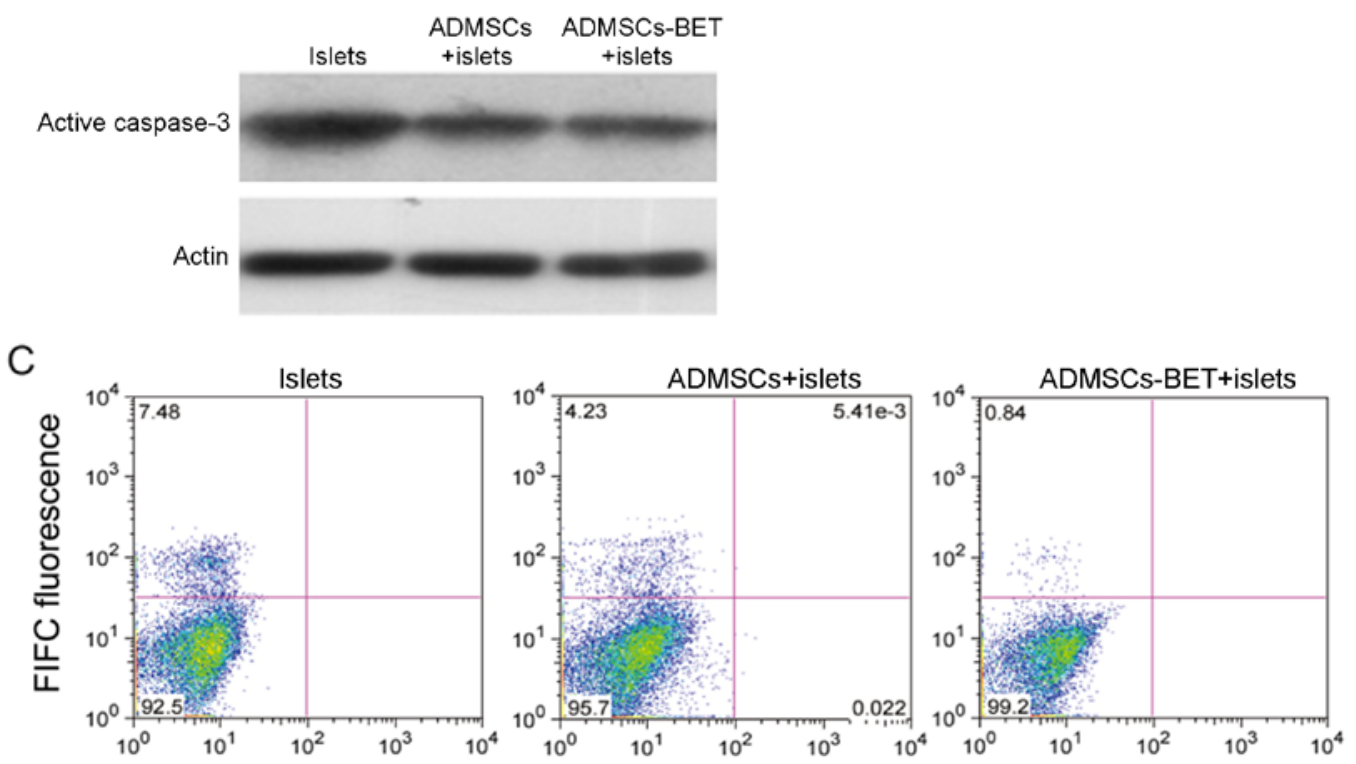

PI fluorescence

Figure 5. Enhanced anti-inflammatory and anti-apoptotic effects of adipose-derived mesenchymal stem cell (ADMSCs)-BET co-cultured with islets. (A) The protein levels of inflammatory- and apoptosis-related proteins in the supernatant of the human islets cultured alone (islet) or with ADMSCs (MSC + islet) or ADMSCs-BET (ADMSCs-BET + islets). Data are presented as the mean \pm standard deviation; $n=3$ for each bar. (B) Western blot analysis of active caspase-3 protein levels in islets cultured alone (islets) or with ADMSCs (ADMSCs + islets) or ADMSCs-BET (ADMSCs-BET + islets). (C) Single cell suspensions derived from different co-culture settings were stained with Annexin V and PI and followed by flow cytometric analysis.

ADMSCs-BET group than in the control or ADMSCs groups (13.64 \pm 1.12 vs. $6.73 \pm 1.24$ and $9.22 \pm 1.89$, respectively; $\mathrm{P}<0.001)$.

\section{Discussion}

In vivo studies and clinical trials have demonstrated that MSCs are capable of reducing blood glucose levels in animal models or in humans with T1D or T2D $(40,41)$. Furthermore, MSCs are ideal cellular delivery vehicles for gene delivery $(42,43)$ without the limitations of viral vector-based gene therapy, such as insertional mutagenesis and the generation of innate, and specific anti-viral immune responses against viral proteins $(44,45)$. In the present study, ADMSCs stably overexpressing betatrophin augmented the therapeutic effects of MSCs in mice with STZ-induced diabetes. Although betatrophin overexpression did not affect ADMSC proliferation, differentiation and morphology, it provided strong paracrine effects and conferred additional cyto-protective effects in vitro and in vivo, leading to greater $\beta$-cell number, increased insulin production and reduced glucose levels.
The application of gene-modified hMSCs expressing human insulin by a retroviral vector has been reported to be able to ameliorate diabetes in rats (46). The same group later reported the reversal of hyperglycemia after the administration of insulin-expressing mMSCs to the liver (47). Similarly, we showed that the transplantation of ADMSCs overexpressing betatrophin improved diabetes in mice with STZ-induced diabetes. Betatrophin is a novel $\beta$-cell mitogen reported by Yi et al (21) that enhances endogenous $\beta$-cell replication and improves glucose tolerance and insulin secretion following hydrodynamic tail injections of plasmids encoding mouse and human betatrophin into mice with insulin resistance induced by the insulin receptor antagonist, S961. However, the effects of betatrophin on human islets were not analyzed (21). Follow-up studies by Jiao et al (48), which injected S961 in an attempt to increase hepatic betatrophin expression in mice, demonstrated that despite the induction of vigorous replication in mouse $\beta$-cells transplanted into renal subcapsular tissues of SCID mice, endogenous betatrophin failed to induce replication in transplanted human $\beta$-cells. In the present study, the impact 

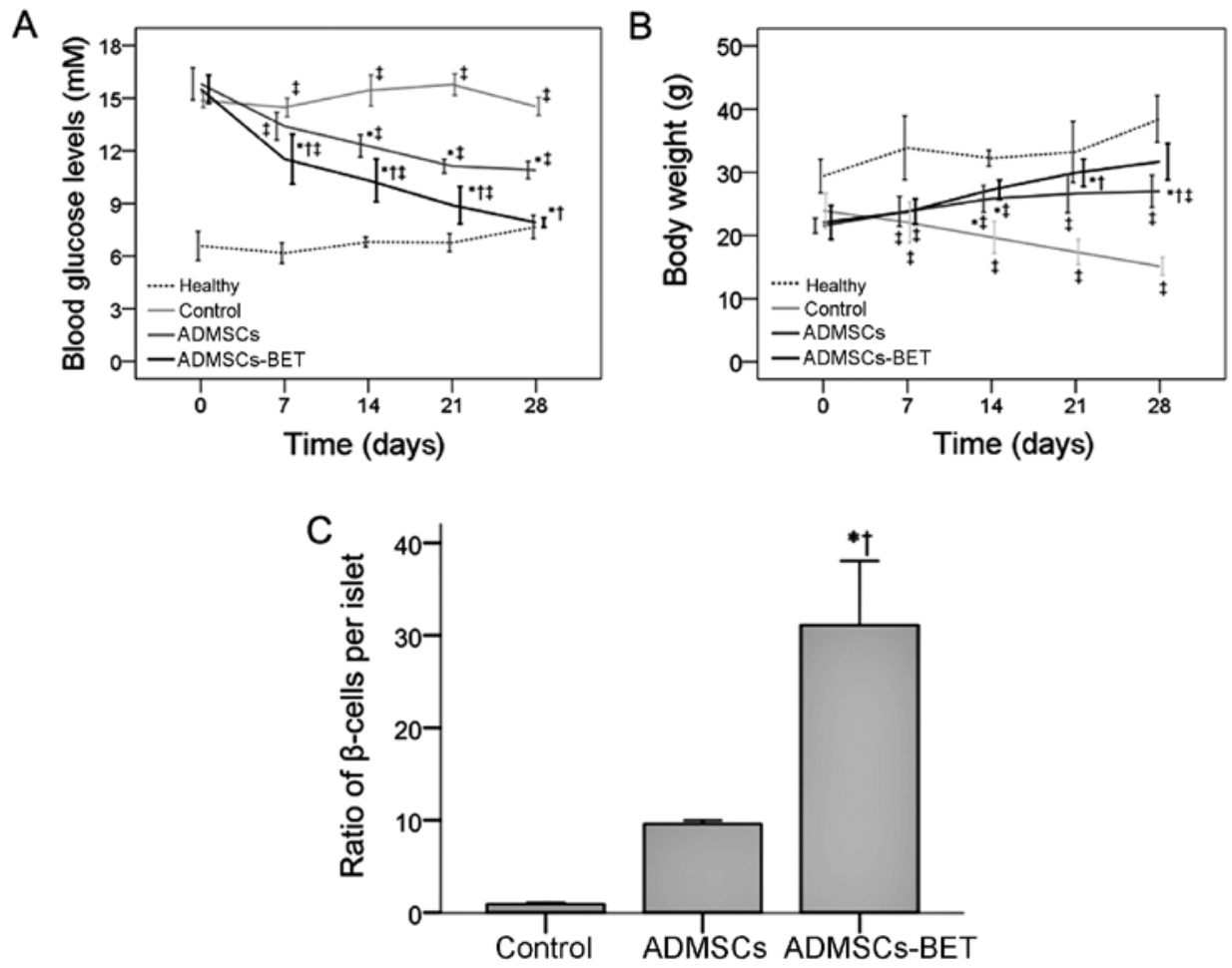

Figure 6. Reversion of the hyperglycemic condition and body weight in mice with streptozotocin (STZ)-induced diabetes by adipose-derived mesenchymal stem cells (ADMSCs). Mice with STZ-induced diabetes were transplanted with 1x106 ADMSCs (ADMSCs) or ADMSCs-BET (ADMSCs-BET) via a tail vein injection. Mice in control group received PBS injected via the tail vein. Blood glucose levels (A) and body weight (B) were determined every 7 days throughout the 28-day study period ( $n=8$ for each line). (C) The ratio of $\beta$-cells in the islets ( $n=3$ for each bar). Data are presented as the means \pm standard deviation. All measurements were all performed on the same day for each group; however, the values for each measurement were plotted to avoid overlapping of SD bars from each group. ${ }^{*+}$ Significant difference as compared with the ${ }^{*}$ control, ${ }^{\dagger}$ ADMSCs and ${ }^{+}$healthy BALB/c groups.
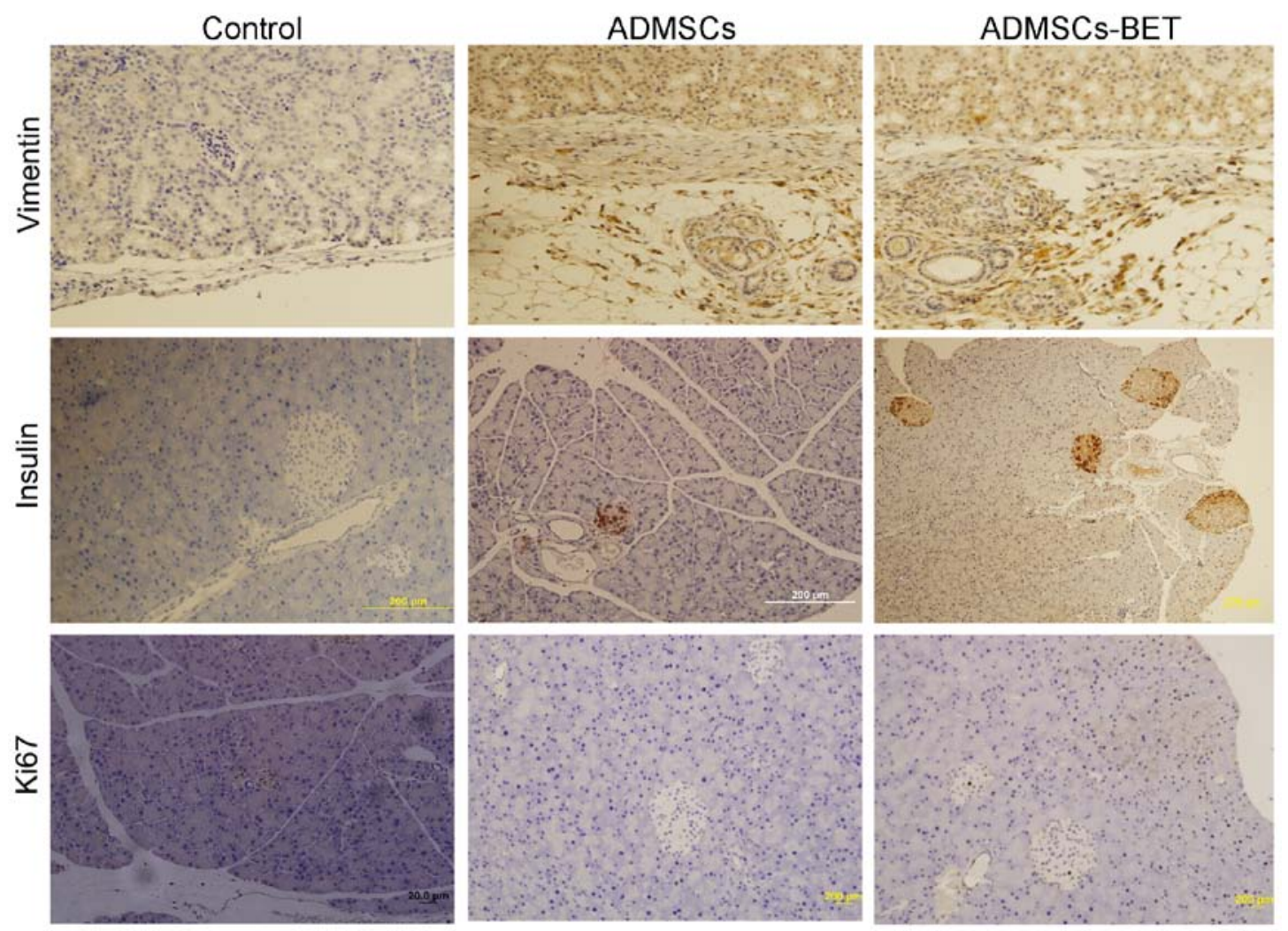

Figure 7. Administration of adipose-derived mesenchymal stem cells (ADMSCs)-BET enhances the proliferation of islets in vivo. Mice with streptozotocin (STZ)-induced diabetes were transplanted with $1 \times 10^{6}$ ADMSCs or ADMSCs-BET (ADMSCs-BET) via a tail vein injection. Mice in control group received PBS injected via the tail vein. The islets were harvested at 7 days following the ADMSC injection, and sections were stained with anti-vimentin (control), anti-insulin, anti-Ki67 antibodies. 
A

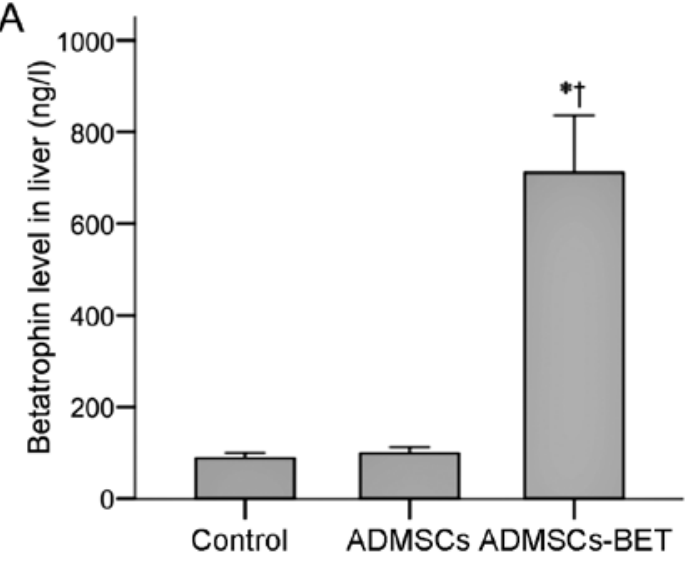

C

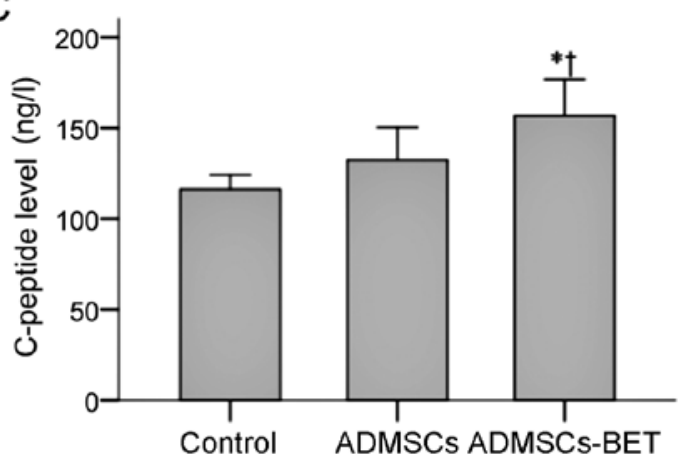

$\mathrm{B}$

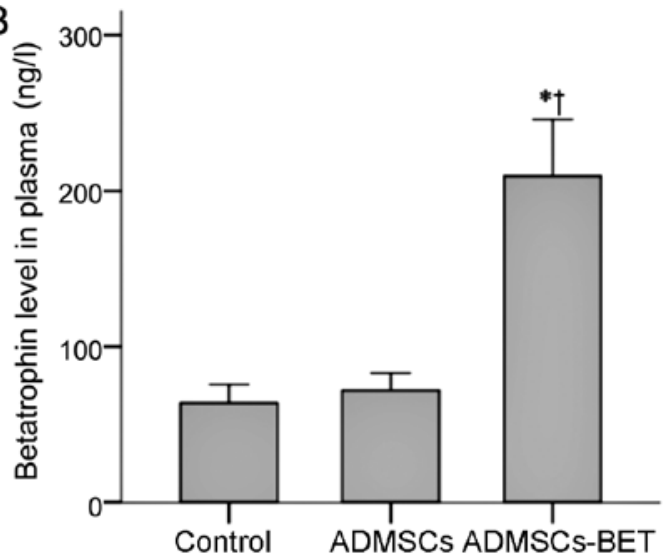

D

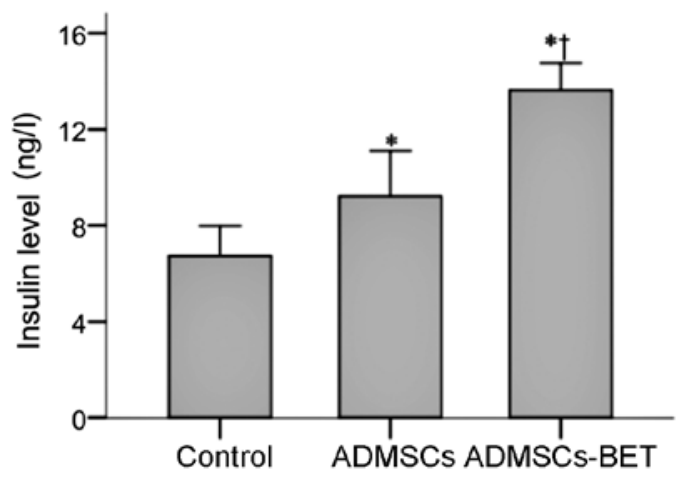

Figure 8. Adipose-derived mesenchymal stem cell (ADMSCs)-BET induce betatrophin overexpression and increased C-peptide and insulin levels in streptozotocin (STZ)-induced diabetic mice. The betatrophin expression levels in (A) liver and (B) blood plasma as well as the levels of plasma (C) C-peptide and (D) insulin were determined on day 28 following injection of ADMSCs (ADMSCs) or those overexpressing betatrophin (MSC-BET). Data are presented as the means \pm standard deviation; $\mathrm{n}=3$ for each bar.

of human ADMSCs-BET was analyzed using co-culture experiments with human islets and in vivo experiments with mice with STZ-induced diabetes. Exposure to ADMSCs-BET increased $\beta$-cell proliferation and insulin levels compared to the control. This findings is different from that reported in the study by Cox et al (49), in which tail vein injections of betatrophin DNA into mice of different ages did not alter $\beta$-cell proliferation. It is possible that the inconsistent responses of human $\beta$-cells to elevated betatrophin may be due to the models employed (i.e., S961-induced insulin resistance vs. STZ-induced diabetes), particularly since S961-induced insulin resistance may be transient and temporary. In addition, the proliferative capability of the islets may vary among mice of different age groups, which may bias the results. Finally, while increased $\beta$-cell proliferation in response to betatrophin may represent the underlying mechanism through which it impacts $\beta$-cell activity, further studies are necessary to fully elucidate the impact of betatrophin overexpression in human $\beta$-cells.

MSCs were initially thought to promote tissue regeneration via direct cell replacement given their capacity to differentiate into a variety of mesenchymal cell types (50). Indeed, autologous MSC transdifferentiation to functional $\beta$-cells has been thought to have the potential to overcome the limitation of the source and the viability of transplanted islets (51). Most protocols applied to induce MSCs along the $\beta$-cell lineage by adding a combination of soluble factors known to influence pancreatic development to the culture medium. The combined suppression or overexpression of certain transcriptional factors was also reported to cause the differentiation of bone marrow MSCs into insulin-producing cells $(52,53)$, suggesting that genetic modifications of MSCs could be performed in vitro to improve MSC efficacy. This is similar to the present study in which ADMSC-BET transplantation induced the ratio of $\beta$-cells per islet, as well as the number of insulin-producing cells over the control and ADMSC groups. Two reasons may explain the increased ratio in the experimental groups: i) an immunoregulatory effect of MSCs that may alleviate islet inflammation, reducing $\beta$-cell apoptosis and ii) $\beta$-cell proliferation by betatrophin (54). However, further studies are necessary to determine the mechanisms involved.

In the present study, the expression of both Ngn3 and Pax6 was increased in the ADMSCs + islet and ADMSCs-BET + islet groups. Ngn3 is a marker for islet progenitor cells, and both Ngn3 and Pax6 are important transcription factors in islet development and differentiation $(55,56)$. In addition, Pax6 is important for $\alpha$-cell differentiation and maturation, which regulates glucagon at the transcriptional level $(57,58)$. Importantly, under conditions that induce extreme $\beta$-cell loss, $\alpha$-cells can convert to $\beta$-cells $(59,60)$. The increased Ngn3 and Pax6 expression in the ADMSCs + islet and ADMSCs-BET + islet groups suggests that the ADMSCs may have differentiated toward islet cells. Furthermore, the expression level of Pax6 in 
ADMSCs-BET + islet group was significantly lower than that in the ADMSCs + islet group, which may be due to differentiation towards $\beta$-cells driven by betatrophin.

Over the past decade, accumulating evidence has indicated that in addition to their role as building blocks for new $\beta$-cells, MSCs ameliorate hyperglycemia in diabetic subjects via their immunomodulatory (41) properties by secreting a diverse array of paracrine factors $(61,62)$. In the present study, islets cultured with ADMSCs-BET had increased IL-4, IL-10 and IL-13 levels and reduced TNF- $\alpha$ and NCP1 levels. We hypothesize that the additional benefits observed with betatrophin overexpression may result from the combination of betatrophin and growth factors secreted by MSCs and/or from the immunomodulatory and anti-apoptotic properties of the ADMSCs. The anti-inflammatory capacity of the ADMSCs observed in the present study was consistent with a previous study by Kuo et al (63), which showed that ADMSCs accelerated diabetic wound healing by reducing the pro-inflammatory environment and increasing growth factor expression.

Wang et al (64) reported that human-derived MSCs can localize to the liver and pancreas following their transplantation into rats with STZ-induced T1DM and may not cause immune rejection. In addition to animal models of diabetes, humanderived MSC transplantation has also been conducted in a rat meniscus injury model (65), as well as other models (66), and these studies suggest that it does not cause immune rejection, which may be due to the low antigenicity of MSCs. Furthermore, as autoimmunity, a key factor in T1DM pathogenesis, may not be observed in severe combined immunodeficient mice (SCID) mice, neither SCID mice nor immunosuppressants were used in the present study.

In conclusion, combining cell transplantation with gene therapy may represent a useful therapeutic tool for the treatment of diabetes. Specifically, betatrophin-overexpressing ADMSCs increased human islet viability and $\beta$-cell insulin secretion in vitro and in vivo, which may be mediated by the enhanced anti-inflammatory and anti-apoptotic potential of ADMSCs with betatrophin overexpression.

\section{Acknowledgements}

This study was supported by grants from the National Natural Science Foundation of China (nos. 81100585, 81100586, $81170718,81270890,81300672$ and 81301722), the Natural Science Foundation of Shanghai Municipality, China (nos. 11nm0504200, 13ZR1410300 and 13ZR1414700), the Youth Foundation of Shanghai Municipal Health Bureau, China (nos. 20114Y115 and 2012J022A), and the Scientific Research Foundation for Junior Teachers of Medicine in the Second Military Medical University, China (no. 2011QN20).

\section{References}

1. Shaw JE, Sicree RA and Zimmet PZ: Global estimates of the prevalence of diabetes for 2010 and 2030. Diabetes Res Clin Pract 87: 4-14, 2010.

2. Atkinson MA and Eisenbarth GS: Type 1 diabetes: New perspectives on disease pathogenesis and treatment. Lancet 358: 221-229, 2001

3. Nyenwe EA, Jerkins TW, Umpierrez GE and Kitabchi AE: Management of type 2 diabetes: Evolving strategies for the treatment of patients with type 2 diabetes. Metabolism 60: 1-23, 2011.
4. Mishra PK, Singh SR, Joshua IG and Tyagi SC: Stem cells as a therapeutic target for diabetes. Front Biosci (Landmark Ed) 15: 461-477, 2010.

5. Couri CE and Voltarelli JC: Stem cell-based therapies and immunomodulatory approaches in newly diagnosed type 1 diabetes. Curr Stem Cell Res Ther 6: 10-15, 2011.

6. Ezquer FE, Ezquer ME, Parrau DB, Carpio D, Yañez AJ and Conget PA: Systemic administration of multipotent mesenchymal stromal cells reverts hyperglycemia and prevents nephropathy in type 1 diabetic mice. Biol Blood Marrow Transplant 14: 631-640, 2008.

7. Deans RJ and Moseley AB: Mesenchymal stem cells: Biology and potential clinical uses. Exp Hematol 28: 875-884, 2000.

8. Conget P, Rodriguez F, Kramer S, Allers C, Simon V, Palisson F Gonzalez S and Yubero MJ: Replenishment of type VII collagen and re-epithelialization of chronically ulcerated skin after intradermal administration of allogeneic mesenchymal stromal cells in two patients with recessive dystrophic epidermolysis bullosa. Cytotherapy 12: 429-431, 2010.

9. Barry FP and Murphy JM: Mesenchymal stem cells: Clinical applications and biological characterization. Int $\mathrm{J}$ Biochem Cell Biol 36: 568-584, 2004.

10. Tang DQ, Cao LZ, Burkhardt BR, Xia CQ, Litherland SA, Atkinson MA and Yang LJ: In vivo and in vitro characterization of insulin-producing cells obtained from murine bone marrow. Diabetes 53: 1721-1732, 2004.

11. Thakkar UG, Trivedi HL, Vanikar AV and Dave SD: Insulin-secreting adipose-derived mesenchymal stromal cells with bone marrow-derived hematopoietic stem cells from autologous and allogenic sources for type 1 diabetes mellitus. Cytotherapy 17: 940-947, 2015.

12. Heineman FW and Balaban RS: Phosphorus-31 nuclear magnetic resonance analysis of transient changes of canine myocardial metabolism in vivo. J Clin Invest 85: 843-852, 1990.

13. Ben-Ami E, Berrih-Aknin S and Miller A: Mesenchymal stem cells as an immunomodulatory therapeutic strategy for autoimmune diseases. Autoimmun Rev 10: 410-415, 2011.

14. Maccario R, Podestà $\mathrm{M}$, Moretta $\mathrm{A}$, Cometa $\mathrm{A}$, Comoli $\mathrm{P}$, Montagna D, Daudt L, Ibatici A, Piaggio G, Pozzi S, et al: Interaction of human mesenchymal stem cells with cells involved in alloantigen-specific immune response favors the differentiation of $\mathrm{CD}^{+} \mathrm{T}$-cell subsets expressing a regulatory/suppressive phenotype. Haematologica 90: 516-525, 2005.

15. Rasmusson I, Ringdén O, Sundberg B and Le Blanc K: Mesenchymal stem cells inhibit lymphocyte proliferation by mitogens and alloantigens by different mechanisms. Exp Cell Res 305: 33-41, 2005.

16. Rasmusson I: Immune modulation by mesenchymal stem cells. Exp Cell Res 312: 2169-2179, 2006.

17. Phinney DG and Prockop DJ: Concise review: mesenchymal stem/ multipotent stromal cells: the state of transdifferentiation and modes of tissue repair - current views. Stem Cells 25: 2896-2902, 2007.

18. Caplan AI and Dennis JE: Mesenchymal stem cells as trophic mediators. J Cell Biochem 98: 1076-1084, 2006.

19. Zhang R: Lipasin, a novel nutritionally-regulated liver-enriched factor that regulates serum triglyceride levels. Biochem Biophys Res Commun 424: 786-792, 2012.

20. Quagliarini F, Wang Y, Kozlitina J, Grishin NV, Hyde R, Boerwinkle E, Valenzuela DM, Murphy AJ, Cohen JC and Hobbs HH: Atypical angiopoietin-like protein that regulates ANGPTL3. Proc Natl Acad Sci USA 109: 19751-19756, 2012.

21. Yi P, Park JS and Melton DA: Betatrophin: A hormone that controls pancreatic $\beta$ cell proliferation. Cell 153: 747-758, 2013.

22. Wang Y, Quagliarini F, Gusarova V, Gromada J, Valenzuela DM, Cohen JC and Hobbs HH: Mice lacking ANGPTL8 (Betatrophin) manifest disrupted triglyceride metabolism without impaired glucose homeostasis. Proc Natl Acad Sci USA 110: 16109-16114, 2013.

23. Chen X, Lu P, He W, Zhang J, Liu L, Yang Y, Liu Z, Xie J, Shao S, Du T, et al: Circulating betatrophin levels are increased in patients with type 2 diabetes and associated with insulin resistance. J Clin Endocrinol Metab 100: E96-E100, 2015.

24. Gómez-Ambrosi J, Pascual E, Catalán V, Rodríguez A, Ramírez B, Silva C, Gil MJ, Salvador J and Frühbeck G: Circulating betatrophin concentrations are decreased in human obesity and type 2 diabetes. J Clin Endocrinol Metab 99: E2004-E2009, 2014.

25. Kugelberg E: Diabetes: Betatrophin - inducing $\beta$-cell expansion to treat diabetes mellitus? Nat Rev Endocrinol 9: 379, 2013.

26. Izadpanah R, Joswig T, Tsien F, Dufour J, Kirijan JC and Bunnell BA: Characterization of multipotent mesenchymal stem cells from the bone marrow of rhesus macaques. Stem Cells Dev 14: 440-451, 2005. 
27. Sekiya I, Colter DC and Prockop DJ: BMP-6 enhances chondrogenesis in a subpopulation of human marrow stromal cells. Biochem Biophys Res Commun 284: 411-418, 2001.

28. Yeung TY, Seeberger KL, Kin T, Adesida A, Jomha N, Shapiro AM and Korbutt GS: Human mesenchymal stem cells protect human islets from pro-inflammatory cytokines. PLoS One 7: e38189, 2012

29. Isaac R, Boura-Halfon S, Gurevitch D, Shainskaya A, Levkovitz Y and Zick Y: Selective serotonin reuptake inhibitors (SSRIs) inhibit insulin secretion and action in pancreatic $\beta$ cells J Biol Chem 288: 5682-5693, 2013.

30. Bivalacqua TJ, Usta MF, Kendirci M, Pradhan L, Alvarez X, Champion HC, Kadowitz PJ and Hellstrom WJ: Superoxide anion production in the rat penis impairs erectile function in diabetes: Influence of in vivo extracellular superoxide dismutase gene therapy. J Sex Med 2: 187-198, 2005.

31. Dominici M, Le Blanc K, Mueller I, Slaper-Cortenbach I, Marini F, Krause D, Deans R, Keating A, Prockop DJ and Horwitz E: Minimal criteria for defining multipotent mesenchymal stromal cells. The International Society for Cellular Therapy position statement. Cytotherapy 8: 315-317, 2006.

32. Kögler G, Sensken S, Airey JA, Trapp T, Müschen M, Feldhahn N, Liedtke S, Sorg RV, Fischer J, Rosenbaum C, et al: A new human somatic stem cell from placental cord blood with intrinsic pluripotent differentiation potential. J Exp Med 200: $123-135,2004$.

33. Niemeyer P, Krause U, Fellenberg J, Kasten P, Seckinger A, Ho AD and Simank HG: Evaluation of mineralized collagen and alpha-tricalcium phosphate as scaffolds for tissue engineering of bone using human mesenchymal stem cells. Cells Tissues Organs 177: 68-78, 2004.

34. Rackham CL, Dhadda PK, Chagastelles PC, Simpson SJ, Dattani AA, Bowe JE, Jones PM and King AJ: Pre-culturing islets with mesenchymal stromal cells using a direct contact configuration is beneficial for transplantation outcome in diabetic mice. Cytotherapy 15: 449-459, 2013.

35. Donath MY and Shoelson SE: Type 2 diabetes as an inflammatory disease. Nat Rev Immunol 11: 98-107, 2011.

36. Barshes NR, Wyllie S and Goss JA: Inflammation-mediated dysfunction and apoptosis in pancreatic islet transplantation: Implications for intrahepatic grafts. J Leukoc Biol 77: 587-597, 2005.

37. Biarnés M, Montolio M, Nacher V, Raurell M, Soler J and Montanya E: Beta-cell death and mass in syngeneically transplanted islets exposed to short- and long-term hyperglycemia. Diabetes 51: 66-72, 2002.

38. Zaccone P, Phillips J, Conget I, Gomis R, Haskins K, Minty A, Bendtzen K, Cooke A and Nicoletti F: Interleukin-13 prevents autoimmune diabetes in NOD mice. Diabetes 48: 1522-1528, 1999.

39. Kaminski A, Kaminski ER and Morgan NG: Pre-incubation with interleukin-4 mediates a direct protective effect against the loss of pancreatic beta-cell viability induced by proinflammatory cytokines. Clin Exp Immunol 148: 583-588, 2007.

40. Jiang R, Han Z, Zhuo G, Qu X, Li X, Wang X, Shao Y, Yang S and Han ZC: Transplantation of placenta-derived mesenchymal stem cells in type 2 diabetes: A pilot study. Front Med 5: 94-100, 2011.

41. Abdi R, Fiorina P, Adra CN, Atkinson M and Sayegh MH: Immunomodulation by mesenchymal stem cells: A potential therapeutic strategy for type 1 diabetes. Diabetes 57: 1759-1767, 2008.

42. Zhu YG, Qu JM, Zhang J, Jiang HN and Xu JF: Novel interventional approaches for ALI/ARDS: Cell-based gene therapy. Mediators Inflamm 2011: 560194, 2011.

43. Devaney J, Contreras M and Laffey JG: Clinical review: genebased therapies for ALI/ARDS: where are we now? Crit Care 15: $224,2011$.

44. Nayak S and Herzog RW: Progress and prospects: Immune responses to viral vectors. Gene Ther 17: 295-304, 2010.

45. Raper SE, Chirmule N, Lee FS, Wivel NA, Bagg A, Gao GP, Wilson JM and Batshaw ML: Fatal systemic inflammatory response syndrome in a ornithine transcarbamylase deficient patient following adenoviral gene transfer. Mol Genet Metab 80: 148-158, 2003

46. Lu Y, Wang Z and Zhu M: Human bone marrow mesenchymal stem cells transfected with human insulin genes can secrete insulin stably. Ann Clin Lab Sci 36: 127-136, 2006.
47. Xu J, Lu Y, Ding F, Zhan X, Zhu M and Wang Z: Reversal of diabetes in mice by intrahepatic injection of bone-derived GFP-murine mesenchymal stem cells infected with the recombinant retrovirus-carrying human insulin gene. World J Surg 31 1872-1882, 2007.

48. Jiao Y, Le Lay J, Yu M, Naji A and Kaestner KH: Elevated mouse hepatic betatrophin expression does not increase human $\beta$-cell replication in the transplant setting. Diabetes 63: 1283-1288, 2014

49. Cox AR, Lam CJ, Bonnyman CW, Chavez J, Rios JS and KushnerJA: Angiopoietin-like protein 8(ANGPTL8)/betatrophin overexpression does not increase beta cell proliferation in mice. Diabetologia 58: 1523-1531, 2015.

50. Volarevic V, Arsenijevic N, Lukic ML and Stojkovic M: Concise review: Mesenchymal stem cell treatment of the complications of diabetes mellitus. Stem Cells 29: 5-10, 2011.

51. Sun Y, Chen L, Hou XG, Hou WK, Dong JJ, Sun L, Tang KX, Wang B, Song J, Li H, et al: Differentiation of bone marrowderived mesenchymal stem cells from diabetic patients into insulin-producing cells in vitro. Chin Med J (Engl) 120: 771-776, 2007.

52. Li HT, Jiang FX, Shi P, Zhang T, Liu XY, Lin XW and Pang XN: In vitro reprogramming of rat bone marrow-derived mesenchymal stem cells into insulin-producing cells by genetically manipulating negative and positive regulators. Biochem Biophys Res Commun 420: 793-798, 2012.

53. Guo QS, Zhu MY, Wang L, Fan XJ, Lu YH, Wang ZW, Zhu SJ, Wang Y and Huang Y: Combined transfection of the three transcriptional factors, PDX-1, NeuroD1, and MafA, causes differentiation of bone marrow mesenchymal stem cells into insulin-producing cells. Exp Diabetes Res 2012: 672013, 2012.

54. Wang Y, Chen X, Cao W and Shi Y: Plasticity of mesenchymal stem cells in immunomodulation: Pathological and therapeutic implications. Nat Immunol 15: 1009-1016, 2014.

55. Laakso M: Not for the eyes only: PAX6 and glucose metabolism. Diabetologia 52: 381-384, 2009.

56. Lyttle BM, Li J, Krishnamurthy M, Fellows F, Wheeler MB, Goodyer CG and Wang R: Transcription factor expression in the developing human fetal endocrine pancreas. Diabetologia 51: 1169-1180, 2008

57. St-Onge L, Sosa-Pineda B, Chowdhury K, Mansouri A and Gruss P: Pax6 is required for differentiation of glucagon-producing alpha-cells in mouse pancreas. Nature 387: 406-409, 1997.

58. Grapp M, Teichler S, Kitz J, Dibaj P, Dickel C, Knepel W and Krätzner R: The homeodomain of PAX6 is essential for PAX6-dependent activation of the rat glucagon gene promoter: Evidence for a PH0-like binding that induces an active conformation. Biochim Biophys Acta 1789: 403-412, 2009.

59. Thorel F, Népote V, Avril I, Kohno K, Desgraz R, Chera S and Herrera PL: Conversion of adult pancreatic alpha-cells to betacells after extreme beta-cell loss. Nature 464: 1149-1154, 2010.

60. Shen J, Cheng Y, Han Q, Mu Y and Han W: Generating insulinproducing cells for diabetic therapy: Existing strategies and new development. Ageing Res Rev 12: 469-478, 2013.

61. English K: Mechanisms of mesenchymal stromal cell immunomodulation. Immunol Cell Biol 91: 19-26, 2013.

62. Tolar J, Le Blanc K, Keating A and Blazar BR: Concise review: Hitting the right spot with mesenchymal stromal cells. Stem Cells 28: 1446-1455, 2010.

63. Kuo YR, Wang CT, Cheng JT, Kao GS, Chiang YC and Wang CJ: Adipose-derived stem cells accelerate diabetic wound healing through the induction of autocrine and paracrine effects. Cell Transplant 25:71-81, 2016.

64. Wang H, Qiu X, Ni P, Qiu X, Lin X, Wu W, Xie L, Lin L, Min J, Lai X, et al: Immunological characteristics of human umbilical cord mesenchymal stem cells and the therapeutic effects of their transplantion on hyperglycemia in diabetic rats. Int $\mathrm{J}$ Mol Med 33: 263-270, 2014.

65. Horie M,Choi H,Lee RH,Reger RL, Ylostalo J, Muneta T, Sekiya I and Prockop DJ: Intra-articular injection of human mesenchymal stem cells (MSCs) promote rat meniscal regeneration by being activated to express Indian hedgehog that enhances expression of type II collagen. Osteoarthritis Cartilage 20: 1197-1207, 2012.

66. Lin CS, Lin G and Lue TF: Allogeneic and xenogeneic transplantation of adipose-derived stem cells in immunocompetent recipients without immunosuppressants. Stem Cells Dev 21: 2770-2778, 2012. 